\title{
Bazı Yerfıstığı (Arachis hypogeae L.) Çeşitlerinin Niğde Koşullarında Yetiştirilebilme Olanaklarının Belirlenmesi
}

\author{
Ramazan İlhan AYTEKIN N *Sevgi ÇALIŞKAN \\ Ömer Halisdemir Üniversitesi Tarım Bilimleri ve Tek. Fakültesi Bitkisel Üretim ve Tek. Böl., Niğde \\ *Sorumlu yazar e-posta (Corresponding author e-mail): sevcaliskan@gmail.com
}

\begin{abstract}
Öz
Yerfıstığında çeşit seçimi verimi ve kaliteyi etkileyen en önemli faktörlerin başında gelmektedir. Yerfıstığı (Arachis hypogeae L.) Niğde koşullarında buğday ve patatese alternatif ürün olarak yetiştirilebileceği düşünülen bir yağ bitkisidir. Bu araştırma, 6 farklı yerfıstığı çeşidinin Niğde koşullarında yetiştirilebilme olanaklarını belirlemek amacıyla, Niğde ili Altunhisar İlçesi Bayat Köyünde tesadüf blokları deneme desenine göre üç tekrarlamalı olarak kurulup, yürütülmüştür. Araştırmaya alınan çeşitlerin bitki başına meyve sayısı, bitki başına meyve verimi, 100-tohum ağırlığı, iç oranı gibi verim parametreleri ile protein oranı ve yağ oranı gibi kalite özellikleri tespit edilmiştir. Araştırma sonucunda, denemede yer alan çeşitlerin bölge koşullarında incelenen özellikler açısından önemli derecede farklılıklar gösterdiği belirlenmiştir. Araştırmada, dekara meyve verimleri 303.4 ile 502.2 kg/da arasında değişmiş olup, en yüksek meyve verimi Osmaniye 2005 çeşidinden elde edilmiştir. Yerfıstığı çeşitlerinin yağ içerikleri \%43.0 ile \%48.9 arasında değişmiş olup, en yüksek yağ içeriği Sultan çeşidinden elde edilmiştir. Araştırma sonuçlarına göre, yetişme süresi kısa, erkenci yerfıstığı çeşitlerinin Niğde koşullarına daha uygun olduğu sonucuna varılmıştır.
\end{abstract}

Anahtar Kelimeler: Arachis hypogeae, çeşit, adaptasyon, verim, kalite

\section{Determination of Growing Possibilities of Some Groundnut (Arachis hypogeae L.) Cultivars in Niğde Conditions}

\begin{abstract}
Cultivar selection is the most important factor affecting yield and quality of groundnut. Groundnut (Arachis hypogeae L.) is an oil plant that can be grown as an alternative to wheat and potato in Nigde conditions. Agronomic and quality characteristics of 6 different groundnut cultivars were investigated in Bayat villages of Altunhisar in Nigde in 2014. The experimental design was randomized completed block with three replications. In this study, parameters as pod number per plant, discard pod rate (\%), 100-seed weight (g), seed rate (\%), pod yield $\left(\mathrm{kg} \mathrm{da}^{-1}\right)$, oil content (\%) and protein content (\%) were evaluated. As a result of research, the cultivars differed significantly with respect to all investigated characters. The results of pod yield ranged from 303.4 and $502.2 \mathrm{~kg} \mathrm{da}^{-1}$ and the highest pod yield was obtained from Osmaniye 2005 cultivar. Oil content of groundnut cultivars was ranged \%43.0 and 48.9 and the highest oil content was obtained from Sultan cultivar. As a result of research, short growth period and early groundnut cultivars are more suitable for Nigde conditions.
\end{abstract}

Keywords: Arachis hypogeae, cultivar, adaptation, yield, quality

\section{Giriş}

ç Anadolu Bölgesi'nin güneydoğusunda yer

alan ve genel olarak karasal iklimin hakim olduğu Niğde ilinde, tarla bitkileri üretimi bugün için geniş anlamda buğday, patates ve fasulye üzerine yoğunlaşmış bulunmaktadır. Bölgede, monokültür tarımın toprak ve işletme verimliliği üzerindeki olumsuz etkileri gün geçtikçe daha iyi anlaşılmaya başlanmıştır. Bununla birlikte, üretimin büyük ölçüde kuru tarıma dayalı olması, tarım yapılan arazilerin toprak verimliliğinin düşük olması ürün artışını olumsuz etkilemektedir. Yine girdi maliyetlerinin yüksekliği, arazilerin küçük ve çok parçalı olması tarım tekniklerinin etkinliğini azaltmakta ve maliyetleri yükseltmektedir (Çalışkan 2013). Bu nedenle, son yıllarda bölge koşullarına uygun alternatif ürün arayışları artmıştır. Bölge koşullarına uygun yetiştirilebilecek bitkilerin belirlenerek, tarımının yaygınlaştırılması, bölge ve ülke ekonomisine önemli katkılar sağlayacaktır. 
Halen ülkemizin Güney kıyı bölgelerinde ticari anlamda tarımı yapılmakta olan yerfıstığı, gerek verim potansiyeli gerekse pazarlama kolaylıkları nedeniyle bölge için en avantajlı alternatiflerden birisidir. Yağ, protein, karbonhidratlar, vitaminler ve madensel maddeler açısından oldukça zengin bir bileşime sahip olan yerfıstığı tohumları, doğrudan çerez olarak tüketildiği gibi fıstık ezmesi, yağ ve sabun elde edilmesinde, pastacılık sanayinde kullanılmakta; baklagil olması nedeniyle yüksek oranda protein içeren sapları kıymetli bir hayvan yemi olarak değerlendirilmektedir. Yerfıstığı bitkisinin çok yönlü değerlendirilebilme özelliği, ürün satış fiyatlarına da yansımakta ve yetiştirildiği yörelerde alternatif tarla bitkilerine göre daha yüksek fiyatlarla alıcı bulmaktadır (İşler ve ark. 1997; Çil ve ark. 2013).

Yerfıstığı bitkisi, $40^{\circ}$ güney ve $40^{\circ}$ kuzey enlem dereceleri arasında çok geniş bir adaptasyon alanına sahip olmasına rağmen, bitki gelişimi ile verim ve kalite oluşumu açısından çevresel faktörlerden önemli derecede etkilenebilmektedir. Virginia tipi yerfıstığı bitkisi, yetişme süresince $2100-2500^{\circ} \mathrm{C}$ sıcaklık toplamına intiyaç duymakta olup, sıcaklık arttıkça yetişme süresi de kısalmaktadır (Banterg et al. 2003; Caliskan ve ark. 2008a). Yerfıstığında, sıcaklık bakımından vejetatif dönem generatif döneme göre daha hassas olup, özellikle tam çiçeklenme ve meyve oluşum döneminde $40^{\circ} \mathrm{C}$ 'yi aşan hava sıcaklığı çiçek sayısını artırmakta, fakat meyve tutma oranını, meyve ağırlığını ve dolayısıyla tohum verimini azaltmaktadır (Vara Prasad et al. 2000; Craufurd 2002). Düşük hava sıcaklıkları yerfıstığında generatif dönemi olumsuz etkilemektedir. Düşük hava sıcaklıklarında ilk çiçeklerin görülmesi gecikir, buna bağlı olarak da ginefor sayısında ve meyve bağlama oranında önemli düzeyde düşme görülür (Talvar et al. 1999; Prasad et al. 2000; Kumar et al. 2012). Niğde ili, iklim özellikleri bakımından yerfıstığı tarımının yoğun olarak yapıldığı Adana ve Osmaniye illerinden büyük ölçüde farklılık göstermektedir.

Yerfıstığı, morfo-agronomik karakterler açısından çok büyük bir genetik varyasyona sahiptir (Singh and Simpson, 1994) ancak bu potansiyelin tam olarak ortaya konulabilmesi için, yetiştirilebilirliğinin belirlenmesinin ardından verim ve kalite yönünden bölge koşullarına en iyi uyabilecek çeşitler ile uygun agronomik tekniklerin belirlenmesine yönelik araştırmalar çok büyük önem taşımaktadır (Çalışkan ve ark. 2000). Bu nedenle, bölgede yerfıstığı üretiminin yapılabilmesi için ürünün üreticiye tanıtılması ve adaptasyon çalışmalarına ağırlık verilerek bölge için uygun çeşitlerin belirlenmesi öncelikli konular arasında yer alması gerekir. Bu açıdan, bazı yerfıstığı çeşitlerinin Niğde koşullarında yetiştirilebilme olanaklarını ortaya koymak ve uygun çeşidi belirlemek amacıyla bu çalışma yürütülmüştür.

\section{Materyal ve Yöntem}

Çalışma, 2014 yılında, Niğde ili Altunhisar ilçesine bağlı Bayat köyünde, özel bir şahsa ait sulanabilir nitelikteki birinci sınıf araziler üzerinde yürütülmüştür. Deneme alanı toprakları $(0-30 \mathrm{~cm}$ derinlikte), tınlı bünyeye sahip olup, kuvvetli alkali karakterde $(\mathrm{pH} 8.77)$ ve çok düşük organik madde içeriğine $(\% 0.5)$ sahiptir. Denemelerin yürütüldüğü Niğde ili genel özellikleri itibariyle karasal iklim kuşağı içerisinde yer almakta olup, denemelerin yürütüldüğü dönemler içerisinde ortalama sıcaklıklar, $12.4^{\circ} \mathrm{C}$ (Ekim) ile $24.7^{\circ} \mathrm{C}$ (Ağustos); ortalama nispi nem değerleri ise \%63.0 (Ekim) ile \%34.8 (Temmuz) arasında değişim göstermiştir. Denemeler süresince 8.5 $\mathrm{mm}$ yağış gerçekleşmiştir.

Denemede, araştırma materyali olarak 6 yerfıstığı çeşidi (Sultan, Halisbey, Osmaniye 2005, Wilson, Brandle ve NC-7) kullanılmıştır. Denemede yer alan çeşitlerden, NC-7 çeşidi yatık, diğerleri yarı yatık gelişme formuna sahiptir.

Deneme, tesadüf blokları deneme desenine göre üç tekrarlamalı olarak kurulup yürütülmüştür. Deneme alanında ön bitki fasulye olup, ön bitkinin hasadından sonra toprak tekniğine uygun olarak hazırlanmış (Arıoğlu 2007); ekim öncesi dekara 10 kg 20-20-0 kompoze gübresi uygulanmış, arkasından diskaro ve sürgü çekilerek toprak ekime hazır hale getirilmiştir. Ekimler, $5 \mathrm{~m}$ uzunluğunda 4 sıradan oluşan parsellere, $70 \times 25 \mathrm{~cm}$ ekim sıklığında, 8 Nisan tarihinde elle yapılmıştır. Ekimden hemen sonra sulama yapılmıştır. 21 Mayısta çıkışlar başlamıştır. Bitkilerin gelişme dönemleri boyunca gerekli bakım işlemleri, tekniğine uygun olarak yapılmıştır (Arıoğlu, 2007). Yetişme dönemi içerisinde tüm parsellere 
Aytekin et al. "Determination of Growing Possibilities of Some Groundnut (Arachis hypogeae L.) Cultivars in Niğde Conditions"

Çizelge 1. Denemeye alınan yerfıstığı çeşitlerinin incelenen tarımsal ve kalite özelliklerine ait ortalama değerler

Table 1. Averages of agronomic and quality characteristics of different groundnut cultivars

\begin{tabular}{|c|c|c|c|c|c|c|c|}
\hline & $\begin{array}{l}\text { Meyve } \\
\text { Sayısı } \\
\text { (adet/bitki) }\end{array}$ & $\begin{array}{l}\text { Iskarta } \\
\text { Meyve } \\
\text { Oranı (\%) }\end{array}$ & $\begin{array}{l}\text { 100- } \\
\text { Tohum } \\
\text { Ağırlığı } \\
\text { (g) }\end{array}$ & $\begin{array}{l}\text { İç } \\
\text { Oranı } \\
(\%)\end{array}$ & $\begin{array}{l}\text { Meyve } \\
\text { Verimi } \\
(\mathrm{kg} / \mathrm{da})\end{array}$ & $\begin{array}{l}\text { Yağ } \\
\text { Oranı } \\
(\%)\end{array}$ & $\begin{array}{l}\text { Protein } \\
\text { Oranı } \\
(\%)\end{array}$ \\
\hline Sultan & $37.3 d$ & $7.7 a$ & $90.5 a b$ & $64.4 \mathrm{bc}$ & $415.5 b$ & $48.9 a$ & $20.7 a$ \\
\hline Halisbey & $40.7 c$ & $6.4 b$ & $94.5 a$ & $60.2 d$ & $484.5 a$ & 46.9ab & $20.2 a b$ \\
\hline $\begin{array}{l}\text { Osmaniye } \\
2005\end{array}$ & $46.6 a$ & 7.0ab & $87.5 b$ & $62.2 \mathrm{~cd}$ & $502.2 \mathrm{a}$ & 46.9ab & $22.5 a$ \\
\hline Wilson & $43.4 b$ & $4.3 c$ & $73.9 c$ & $66.5 b$ & $360.8 \mathrm{c}$ & $45.9 b$ & $17.3 \mathrm{c}$ \\
\hline Brandle & $27.4 f$ & $6.7 a b$ & $92.5 a b$ & $62.8 \mathrm{~cd}$ & $303.7 d$ & $43.0 \mathrm{c}$ & $18.2 \mathrm{bc}$ \\
\hline NC-7 & $30.6 e$ & $2.9 d$ & $87.2 b$ & $70.1 \mathrm{a}$ & $347.8 \mathrm{c}$ & $44.6 b c$ & $20.7 a$ \\
\hline Ortalama & 37.7 & 5.8 & 87.7 & 64.4 & 402.4 & 46.1 & 19.9 \\
\hline LSD (\%5) & 2.62 & 1.13 & 5.78 & 3.03 & 21.9 & 2.66 & 2.43 \\
\hline Tekerrür & 1.45 & 0.13 & 3.92 & 1.49 & 215.71 & 4.67 & 1.40 \\
\hline Uygulama & $166.94^{* *}$ & $10.14^{* *}$ & $161.20^{* *}$ & $37.24^{* *}$ & $18799.42^{* *}$ & $12.69^{* *}$ & $0.55^{* *}$ \\
\hline Hata & 2.08 & 0.39 & 10.11 & 2.78 & 145.22 & 2.51 & 1.79 \\
\hline DK (\%) & 3.82 & 10.68 & 3.62 & 2.59 & 2.99 & 3.18 & 6.71 \\
\hline
\end{tabular}

**: Varyans analizinde çeşitler arasındaki farklılık \%1 düzeyinde önemlidir

**. Differences among varieties are significant at \%1 level

çiçeklenme başlangıcında $10 \mathrm{~kg} / \mathrm{da} \% 46$ 'ık üre gübresi ile ginefor oluşum döneminde $20 \mathrm{~kg} / \mathrm{da}$ \%33'lük amonyum nitrat gübresi (Çalışkan ve Arıoğlu, 2001) uygulanmıştır. Hasat dönemlerine yaklaşıldıkça zaman zaman parsellerden bitkiler çekilip, bitki ve meyvelerin gelişme durumlarına bakılarak hasat olgunluğu tespit edilmeye çalışıımış ve 8 Kasım tarihinde, her parselin orta iki sırasında bulunan bitkiler hasat edilmiştir. Hasat sırasında sıraların her iki ucunda bulunan bitkiler kenar tesiri olarak bırakılmıştır.

Hasat öncesinde her parselden tesadüfi olarak alınan 10 bitkide meyveler sayılmış, ıskarta meyveler ayrılarak tartılmış ve $\%$ oranları belirlenmiştir. Hasat sonrasında her parselden sökülen meyveler, ayrı ayrı örtüler üzerinde yaklaşık \%10 nem düzeyine ulaşıncaya kadar kurutulmuş ve ardından parsel verimleri hesaplanmıştır. Parsel verimlerinin dekara oranlaması ile de dekara meyve verimleri hesaplanmış; bitki basına meyve sayısı (adet/bitki), iç oranı (\%) ve 100-tohum ağırlıkları (g) belirlenmiştir. Her uygulamadan alınan ve kurutulup öğütülen tohum örneklerinde yağ oranları soxhlet cihazında petrol eteri ekstraksiyonu ile protein oranları ise yaş yakma metodu ile hazırlanarak Kjeldahl aletine bağlanmış ve protein oranı \% olarak belirlenmiştir.

\section{Bulgular ve Tartışma}

Denemede yer alan çeşitlerin, incelenen özellikler açısından oluşturdukları ortalama değerler Çizelge 1'de verilmiştir. Araştırma sonucunda, denemede yer alan yerfıstığı çeşitlerinin bitki başına ortalama meyve sayısının 27.4 ile 46.6 adet/bitki arasında değişim gösterdiği saptanmıştır (Çizelge 1). Yerfıstığı bitkisi sıcaklık toplamına bağlı olarak çıkıştan yaklaşık 35-50 gün sonra çiçeklenmeye başlayıp (Çalışkan ve ark. 2008b), yetişme dönemi sonuna kadar çok sayıda çiçek oluşturmakta, ancak oluşturulan çiçeklerin sadece çok az bir kısmı (\%10 civarında) meyve oluşturabilmektedir (Çalışkan ve ark. 2008c). Çalışmamızda en yüksek meyve sayısına sahip olan Osmaniye 2005 çeşidi diğer çeşitlere oranla daha erken çiçeklenmeye geçen bir çeşittir (Çalışkan ve ark. 2008a). Bununla birlikte, gerek çiçeklenmeye başlama dönemi, gerekse çiçeklerin meyve oluşturma oranı, çeşitlerin genetik yapısı yanında çevre şartları ve yetiştirme tekniklerinden önemli derecede etkilenmektedir (Çalışkan ve ark. 2008a). Iskarta meyve oranının düşük olması istenen bir özellik olup, çeşitlere göre farklılık göstermiştir. Iskarta meyve oranı çeşitlere göre büyük farklııı göstermiş \%2.9 ile \%7.7 arasında değişim göstermiştir. 
Bitkilerin morfolojik özellikleri yanında 100tohum ağırığı ve iç oranı gibi meyve ve tohum özellikleri açısından da çeşitler arasında önemli farklıııklar ortaya çıkmıştır. Ülkemizde yerfıstığının büyük çoğunluğu çerezlik olarak tüketilmesi nedeniyle tohum iriliklerinin fazla olması istenmektedir. Arıoglu (2007) çerezlik olarak yetiştirilen yerfıstığında 100-tohum ağırlığının 80 g'ın üzerinde olması gerektiğini bildirmektedir. Farklı yerfıstığı tipleri içerisinde özellikle Virginia ve Runner tipi yerfıstıkları daha iri tohumlara sahiptir (Arıoglu ve ark. 2000). Çizelge 1 'de görüldüğü gibi denemede yer alan çeşitlerin ortalama 100-tohum ağırıkları $73.9 \mathrm{~g}$ (Wilson) ile $94.5 \mathrm{~g}$ (Halisbey) arasında değişim göstermiş̧ir.

İç oranının yüksek olması ürün randımanını artıracağı için gerek çerezlik gerekse yağlık yerfıstığı alımı yapan kişi ve kuruluşlar tarafından daha fazla tercih edilmektedir (Arıoğlu 2007). Ramanatha and Murty (1994) yerfıstığında iç oranının çeşit ve yetiştirme koşullarına bağlı olarak \%60-80 arasında değişim gösterdiğini bildirmektedir. Çizelge 1'de görüldüğü gibi, denemeye alınan genotiplerin iç oranları ortalama olarak \%60.2 ile \%70.1 arasında değişim göstermiş, en yüksek iç oranı halen ülkemizde yaygın olarak üretilmekte olan NC-7 çeşidinden elde edilirken, en düşük iç oranı Halisbey çeşidinden elde edilmiştir. Bununla birlikte elde edilen iç oranı değerlerinin çoğunlukla Arıoglu (2007) tarafından belirtilen sınırlar içerisinde olduğu görülmektedir (Çizelge 1).

Niğde koşullarında yürütülmüş olan bu araştırma sonucunda, meyve verimi değerlerinin çeşitlere göre ortalama olarak 303.7 ile 502.2 $\mathrm{kg} / \mathrm{da}$ arasında değişim gösterdiği, en yüksek verimlerin Osmaniye 2005 ve Halisbey çeşitlerinden (sırasıyla, 502.2 ve $484.5 \mathrm{~kg} / \mathrm{da}$ ) elde edildiği gözlemlenmiştir (Çizelge 1). Knauft and Gorbet (1989), yerfıstığında önemli genotip $x$ çevre interaksiyonlarının görüldüğünü ve yerfıstığı genotiplerinin farklı çevrelerdeki adaptasyon yeteneği ve verim stabilitelerinin farklı olduğunu bildirmiştir. Yağ oranı, yerfıstığı tohumlarının en önemli kalite kriterlerinden birisi olup, çeşitlerin genetik yapıları yanında, çevre şartlarından da önemli derecede etkilenmekte ve $\% 40$ ile \%60 arasında değişebilmektedir (Arıoğlu
2007). Niğde koşullarında yapılan bu çalışmada, yağ oranı açısından da çeşitler arasında önemli farklııklar tespit edilmiş, en yüksek yağ oranı $\% 48.9$ ile Sultan çeşidinden elde edilirken, bunu \%46.9 ile Halisbey ve Osmaniye 2005 çeşitleri izlemiştir (Çizelge 1). En düşük yağ oranı ise \%43.1 ile Brandle çeşidinden elde edilmiştir (Çizelge 1). Yerfıstığında yağı alındıktan sonra geriye kalan küspe değerli bir gıda maddesidir. $\mathrm{Bu}$ nedenle protein oranının yüksek olması istenen bir özelliktir. Niğde koşullarında yapılan bu çalışmada da, protein oranı açısından da çeşitler arasında çok önemli farklııklar tespit edilmiş, en yüksek protein oranı $\% 22.5$ ile Osmaniye çeşidinden elde edilirken, bunu \%20.7 ile Sultan çeşidi izlemiştir (Çizelge 1). En düşük protein oranı ise $\% 17.3$ ile Wilson çeşidinden elde edilmiştir (Çizelge 1).

\section{Sonuç}

Verim ve kalite oluşumuna etkili özelliklerin, çeşitler arasında önemli değişkenlik göstermesi, doğal olarak verim ve kalite özelliklerinin de çeşitlere göre önemli derecede farklılık göstermesine neden olmuştur. En yüksek verimlerin elde edildiği ve yöreye en iyi adaptasyon yeteneğine sahip Osmaniye 2005 ve Halisbey çeşitlerinin bölge için oldukça ümitvar olduğunu göstermektedir. Erkenci çeşitlerinin Niğde koşullarına daha uygun olduğu sonucuna varılmıştır.

\section{Kaynaklar}

Arıoğlu H., 2007. Yağ Bitkileri Yetiştirme ve Islahı. Ç.Ü Ziraat Fakültesi Genel Yayın No: 220

Arıoğlu H., Çalışkan M.E., Çalışkan S., 2000. Doğu Akdeniz koşullarına uygun yerfıstığı çeşitlerinin geliştirilmesi üzerine araştırmalar. M.K.Ü. Ziraat Fak. Dergisi, 5(1-2): 7-28

Banterng P., Patanothai A., Pannangpetch K., Jogloy S., Hoogenboom G., 2003. Seasonal variation in the dynamic growth and development traits of peanut lines. J. Agr. Sci., 141: 51-62

Çalışkan S., Arıoğlu H., 2001. Yerfıstığı (Arachis hypogeae L.) Tarımında Bakteri ve Azotlu Gübre Uygulamalarının Verim ve Kalite Özelliklerine Etkisi”, Türkiye IV. Tarla Bitkileri Kongresi, 17-21 Eylül, Cilt: 2 (Endüstri Bitkileri), Tekirdağ, s: 303-306 
Çalışkan M.E., Mert M., İşler N., Çalışkan S., 2000 Hatay yöresinde ii. ürün olarak yetiştrilen virginia tipi bazı yerfıstığı (Arachis hypogaea L. subs. hypogaea var. hypogaea) genotiplerinin önemli tarımsal ve kalite özellikleri ile bu özelliklerin verim olusumuna etkileri. Türk. J. Agric. Forestry, 24: 87-94

Calıskan S., Calıskan M.E., Erturk E., Arslan M., Arıoglu H., 2008a. Growth and development of Virginia type groundnut cultivars under mediterranean conditions. Acta Agriculturae Scandinavica Section B-Soil and Plant Science, 58(2): 105-113

Caliskan S., Caliskan M.E., Arslan M., Arıoglu H., 2008b. Effects of sowing date and growth duration on growth and yield of groundnut in a Mediterranean-type environment in Turkey. Field Crops Research, 105: 131-140

Caliskan S., Caliskan M.E., Arslan M., 2008c. Genotypic differences for reproductive growth, yield, and yield components in groundnut (Arachis hypogaea L.). Turkish Journal of Agriculture and Forestry, 32(5): 415-424

Çalışkan S,. 2013. İç anadolu bölgesinde yağ bitkilerinin mevcut durumu, sorunları ve çözüm önerileri. Türk Tarım-Gıda Bilim ve Teknoloji Dergisi, 1(1): 17-22

Çil A.N., Çil A., Akkaya M.R., Şahin V., 2013. Doğu Akdeniz Bölgesi Koşullarına Uygun Yerfıstığı (Arachis hypogaea L.) Çeşitlerinin Geliştirilmesi. Türkiye 10 Tarla Bitkileri Kongresi, 10-13 Eylül Konya, Cilt II Endüstri Bitkileri ve Biyoteknoloji, 249-255

Craufurd O.Q., Vara Prasad P.V., Summerfield R.J., 2002. Dry matter production and rate of havest index and high temperature in peanut. CropScience, 42: 146-151

Işler N., Çalışkan M.E., Boydak E., 1997. Virginia Tipi Bazı Yerfıstığı (Arachis hypogaea L.) Çeşitlerinin Şanlıurfa Bölgesi Ana Ürün Koşullarındaki Verimi ile Bitkisel Özelliklerinin Belirlenmesi. Türkiye II. Tarla Bitkileri Kongresi, 22-25 Eylül, Samsun, 631633
Knauft D.A., Gorbet D.W., 1989. Analysis of peanut production in stress and non-stress environments. Tropical Agriculture, 66(3): 243-248

Kumar U., Singh P., Boote K.J., 2012. Effect of climate change factors on processes of crop growth and yield of groundnut (Arachis hypogaea L.). 116: 41-69. DOI: http://dx.doi.org/10.1016/B978-0-12-3942777.00002-6

Prasad P.V.V., Craufurd P.Q. and Summerfield R.J., 2000. Effect of high air and soil temperature on dry matter production, pod yield and yield components of groundnut. Plant Soil, 222: 231-239

Ramanatha Rao V., Murty U.R., 1994. BotanyMorphology and Anatomy. The Groundnut Crop, A Scientific Basis for Improvement (Ed.: Smart J.). Chapman \& Hall, London, 43-95

Singh A.K., Simpson C.E., 1994. Biosystematics and Genetic Resources. The Groundnut Crop, A Scientific Basis for Improvement (Ed.: Smart J.). Chapman \& Hall, London, 96-137

Talwar H.S., Takeda H., Yashima S., Senboku T., 1999. Growth and photosynthetic responses of groundnut genotypes to high temperature. Crop Sci., 39(2): 460-466

Vara Prasad P.V., Craufurd P.Q., Summerfield R.J., 2000. Effect of hight hair and soil temperature on dry matter production, pod yield and yield components of groundnut. Plant and Soil Sci., 222: 231-239 